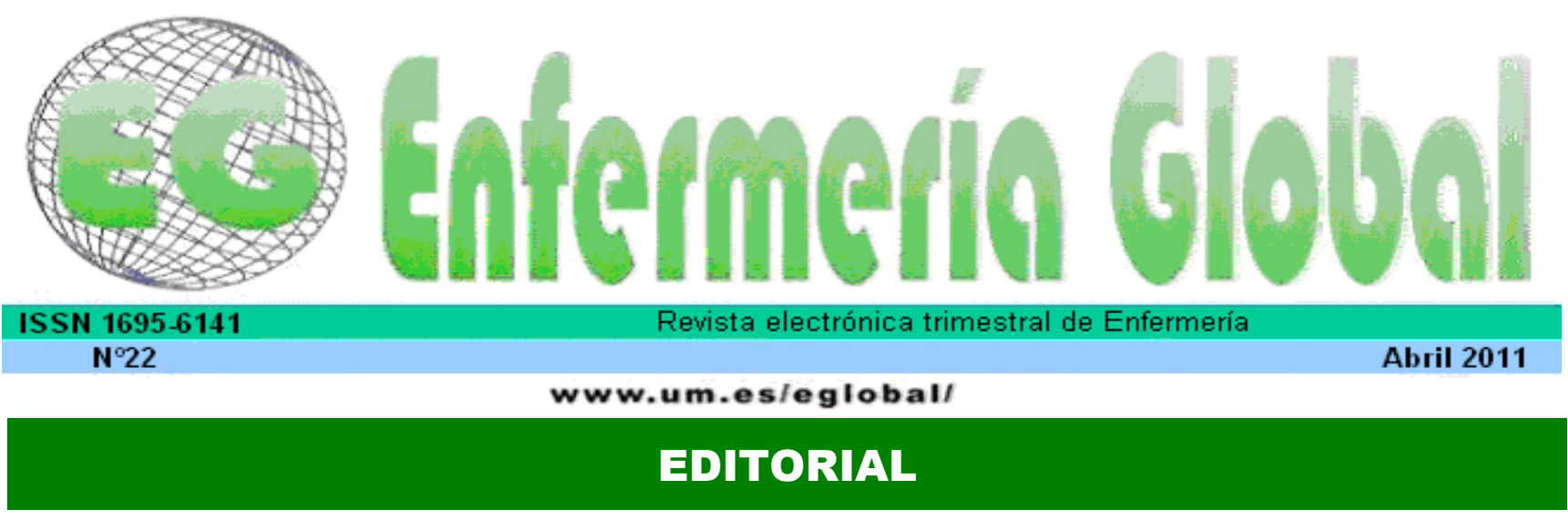

\title{
AYUDEMOS A JAPÓN
}

El número de víctimas debido al seísmo y posterior tsunami ocurridos en Japón el pasado 11 de marzo que los medios de comunicación nos informan al escribir estas líneas, asciende ya a 27.000, y no se quedará ahí, pues son todavía muchas las personas que continúan desaparecidas. Pero lo peor puede estar por llegar, ya que desastres de esta magnitud han dejado históricamente constancia de ser un preámbulo de posteriores problemas relacionados con la salud, como enfermedades y hasta epidemias derivadas de sus consecuencias. Y todo ello sin mencionar la amenaza latente de la radiación que por el momento no parece que pueda ser controlada y que está contaminando el agua y los alimentos de las zonas más próximas.

Los profesionales de la salud siempre se han sentido especialmente sensibilizados ante hechos como los mencionados, haciendo de portavoces para solicitar ayuda, e incluso los más valientes, ayudando directamente.

Desde Enfermería Global nos unimos a ese dolor que tantas personas están padeciendo, y consideramos una obligación profesional y moral el hacer una llamada a todos nuestros lectores, ante los más de 100.000 niños que se encuentran desplazados en Japón después de haber perdido a sus familias, y a los miles de damnificados que deambulan por ciudades, ahora fantasmas, para que contacten con Asociaciones, ONG,s e Instituciones que, en estos momentos, nos informan de cómo ayudar a estas personas.

No olvidemos las palabras del gran filósofo griego Sófocles, "la obra humana más bella es la de ser útil al prójimo".

Mํㅡosé López Montesinos 
ISSN 1695-6141

(C) COPYRIGHT Servicio de Publicaciones - Universidad de Murcia 